\title{
Prevalence of vitamin D deficiency and its associated risk factors among rural population of the northern part of the Persian Gulf
}

Maryam Marzban ${ }^{1} \mathbb{B}$, Mohammadreza Kalantarhormozi ${ }^{2} \mathbb{D}$, Mehdi Mahmudpour ${ }^{1} \mathbb{D}$, Afshin $\operatorname{Ostovar}^{3} \mathbb{D}$, Saeed Keshmiri ${ }^{4} \mathbb{D}$, Amir Hossein Darabi ${ }^{1} \mathbb{D}$, Abdolmohammad Khajeian ${ }^{5}$ (D), Amirreza Bolkheir ${ }^{1}$ (D) Azam Amini ${ }^{6}$ (D) and Iraj Nabipour ${ }^{1 *}$ (D)

\begin{abstract}
Background: Accumulating evidence indicates that vitamin D deficiency has been increased globally over the last two decades. However, the majority of these studies are concerned with cities and there is scant information regarding the prevalence of vitamin $D$ in rural areas. The main aim of this study was to investigate the prevalence of vitamin D deficiency and its associated risk factors among the rural population in Bushehr province which shares the longest border with the Persian Gulf.

Methods: The rural inhabitants of more than 25 years old from three mountainous, plain, and seashore areas of Bushehr province were selected through a stratified multi-cluster random sampling method. After obtaining the participants' demographic and anthropometric data and their past medical history, serum 25-hydroxyvitamin D [25(OH)D] was measured using ELISA.

Results: A total of 1806 (means \pm SD, $46 \pm 14$ years old) rural subjects (35\% males and $65 \%$ females) participated in this study. The prevalence of vitamin D deficiency, insufficiency, and sufficiency were $28 \%, 50 \%$, and $22 \%$, respectively. The deficiency of vitamin $\mathrm{D}$ in women was higher than in men (OR=1.27, $95 \% \mathrm{Cl}: 1.05$ to $1.54, P=0.04)$. There was a positive significant correlation between age and serum vitamin $D$ levels. Men with vitamin $D$ deficiency had higher BMI $(P=0.008)$; this association was not observed among women $(P=0.7)$. There was no significant difference between the food item's consumption frequencies, and vitamin D status $(P>0.05)$. The mountainous, and plain areas had the highest and lowest vitamin D levels, respectively.

Conclusions: Although, Bushehr province is located in a sunny part of Iran, the prevalence of vitamin D deficiency was high among its rural population. The shift of their lifestyle patterns and rapid industrialization in these rural areas may be responsible. Therefore, the enrichment of dietary sources with vitamin $D$ and the use of vitamin $D$ supplements are recommended to tackle the high prevalence of vitamin D deficiency in the rural population of the northern part of the Persian Gulf.
\end{abstract}

Keywords: Vitamin D deficiency, Prevalence, Rural, Enrichment, Iran

\footnotetext{
*Correspondence: inabipour@gmail.com

${ }^{1}$ The Persian Gulf Tropical Medicine Research Center, The Persian Gulf Biomedical Sciences Research Institute, Bushehr University of Medical Sciences, Bushehr, Iran

Full list of author information is available at the end of the article
}

(c) The Author(s). 2021 Open Access This article is licensed under a Creative Commons Attribution 4.0 International License, which permits use, sharing, adaptation, distribution and reproduction in any medium or format, as long as you give appropriate credit to the original author(s) and the source, provide a link to the Creative Commons licence, and indicate if changes were made. The images or other third party material in this article are included in the article's Creative Commons licence, unless indicated otherwise in a credit line to the material. If material is not included in the article's Creative Commons licence and your intended use is not permitted by statutory regulation or exceeds the permitted use, you will need to obtain permission directly from the copyright holder. To view a copy of this licence, visit http://creativecommons.org/licenses/by/4.0/ The Creative Commons Public Domain Dedication waiver (http://creativecommons.org/publicdomain/zero/1.0/) applies to the data made available in this article, unless otherwise stated in a credit line to the data. 


\section{Introduction}

The deficiency of vitamin D has been reported from all parts of the world, and there is a significant association between low serum levels of vitamin D and communicable and non-communicable diseases [1]. Accumulating evidence has shown that vitamin D presents beneficial effects on our tissues and organs.

Besides this, the more vitamin $\mathrm{D}$ concentration means the less occurrence of cancer and the related mortalities. In addition, vitamin $\mathrm{D}$ deficiency has significant association with high blood pressure, type I diabetes, multiple sclerosis, rheumatoid arthritis, and other autoimmune diseases [2].

Vitamin D deficiency has been defined at cut point serum levels of less than $20 \mathrm{ng} / \mathrm{ml}$ because at this level, parathyroid hormone begins to increase. Hence, this cut point is considered the physiologic definition for vitamin D deficiency [3]. However, the results of health outcome assessment of different studies indicated that all-cause mortality [4], cardiovascular diseases [5-7] breast and colorectal cancers [8, 9], diabetes mellitus $[10,11]$ acute respiratory tract infections [12] and SARSCoV-2 positivity [13] appeared beyond the current target $25(\mathrm{OH}) \mathrm{D}$ concentration of $30 \mathrm{ng} / \mathrm{mL}(75 \mathrm{nmol} / \mathrm{L})$ for vitamin $\mathrm{D}$ deficiency. It is interesting that some of the aforementioned outcomes continued to improve up to $25(\mathrm{OH}) \mathrm{D}$ levels of $60-80 \mathrm{ng} / \mathrm{ml}$.

Insufficient sunlight exposure, age- related decrease in vitamin D synthesis in skin, and low dietary intake are attributing factors for circulating levels of this vitamin. Therefore, vitamin D supplementation and sufficient sunlight exposure can protect most of the people from vitamin D deficiency. Five to ten minutes of direct sunlight exposure on the arms and legs between 10:00 AM to 3:00 PM during spring, summer, and autumn can prevent vitamin D insufficiency [14].

Because of the significant effect of vitamin $\mathrm{D}$ on bone mineral homeostasis, bone mineral density, and finally pick bone mass, several large multi-central interventional studies with vitamin D supplementation are under investigations in all over the world [15].

Even though there is a limited amount of vitamin D in plants, a sufficient amount of vitamin D3 could be found in fish oil, calf of liver, cheese, and eggs yolk [16]. In addition, acute liver failure, nephrotic syndrome, renal disease, rickets and hyperparathyroidism could be considered as etiologies for vitamin D insufficiency [6]. The geographical location, methods of skin coverage, skin color, and consumption of foods with lack of vitamin D are prominent causes for vitamin D insufficiency [16].

In a survey study which was done on American population from 2001 to 2006 (National Health, and Nutrition Examination Survey), it was shown that $32 \%$ of participants had serum vitamin D level less than $20 \mathrm{ng} /$ $\mathrm{ml}$ [17]. The studies in developing countries have shown that osteoporosis, increased risk of falling, and bone fracture were associated with an increase in the prevalence of vitamin D deficiency [18].

Moreover, the past two decades studies elucidated a high prevalence of vitamin D deficiency in China, Turkey, Saudi Arabia, and Iran which varied between 30 to $93 \%$ [19].

Vitamin D deficiency was reported in $75.1 \%$ of females and $72.1 \%$ of males from the Iranian Multi-Centric Osteoporosis Studies (IMOS). The result of this study was consistent with those results that had been reported with other studies from the Middle East region. [20]. A comprehensive epidemiological and ecological descriptive study on vitamin D status in Iran showed that the mean of vitamin D concentration was $25.4 \mathrm{ng} / \mathrm{ml}$ which was in the range of vitamin D insufficiency [21].

The high prevalence of vitamin D deficiency among the Iranian population may be due to the shift of Iranian lifestyle patterns towards the urbanization and industrialized lifestyles resulting in low sunlight exposure that accentuates the low dietary intake of vitamin $\mathrm{D}$ in this country [20]. In addition, air pollution is an important affecting factor for vitamin D deficiency in the large cities [22]. Although similar prevalence rates for vitamin D deficiency in urban and rural areas of Asia have been reported, in some studies, the urban subjects in comparison to the rural subjects had more prevalence of vitamin D deficiency [15].

In Iran, the majority of studies have been done in urban areas and capital cities [19, 23, 24]. There is a lack of information about the prevalence of vitamin D deficiency and its serum levels in rural areas [19].

Therefore, the limited information about vitamin D in rural areas may prevent to design strategies to combat vitamin $\mathrm{D}$ deficiency in Iranian rural subjects who are rapidly changing their lifestyle towards urbanization and industrialization. Hence, this phenomenon may accelerate the situation of vitamin D deficiency among this rural population. The aim of this study was to investigate the prevalence of vitamin D deficiency and its associated risk factors among rural population in Bushehr province which has the longest border with the Persian Gulf.

\section{Materials and methods}

\section{Community sampling}

Bushehr province which is located in the northern part of the Persian Gulf, was divided in three geographical (the northern, the central, and the southern) parts. Each geographical part was then divided into three mountainous, plain, and seashore areas in order to assess the effect of latitude, dietary habits, and socio-economic status of inhabitants on their serum vitamin D levels. The 
sample size of each part was proportional to the size of each population. The household was selected as the sampling unit which were randomly selected systematically using national census data.

A total of 1806 rural inhabitants with $\geq 25$ years old were selected. The exclusion criteria included being non-native, inability to give blood sample, disability to answer the questions, and being less than 25 years old. The participants completed a questionnaire including their anthropometric, demographic data, past medical history, gravidity, menopausal status, nutritional conditions and supplementary consumptions as well as their drug history.

\section{Examinations}

Examination were conducted in the primary health care centers attached to Bushehr University of Medical Science (BUMS). Height, and weight were measured using stadium meter. Heavy outer garments, and shoes were removed before measuring heights, and weights. Body mass index (BMI) was calculated. Waist circumference was defining at the mid waist level between the costal margin and iliac crest. Hip circumference was measured at the greater trochanters. A 3 milliliter $(\mathrm{ml})$ sample of blood was taken from all participants, and all samples were promptly centrifuged, and sera were separated, and kept frozen at -80 until they were used.

Serum vitamin D levels were measured using a commercial ELISA kit Immunodiagnostic Systems Limited (The Boldons, United Kingdom). The reportable range of the assay was $6.5-100 \mathrm{ng} / \mathrm{ml}$. Its limit of detection was $2.7 \mathrm{ng} / \mathrm{ml}$. The range of inter-assay $\% \mathrm{CV}$ of the kit was 1.9 to $3.7 \mathrm{ng} / \mathrm{ml}$.

Serum 25(OH)D levels were defined sufficient if they were between 30 and $100 \mathrm{ng} / \mathrm{ml}$, insufficient if varied between $20-<30 \mathrm{ng} / \mathrm{ml}$, and deficient at levels of $<20 \mathrm{ng} /$ $\mathrm{ml}$.

\section{Statistics}

The statistical analysis was performed using STATA version 14 (StataCorp Pty Ltd, College Station, TX, USA). The Kolmogorov-Smirnov test (KS-test) was used to determine the normality of data distribution. For descriptive data, frequency, mean, median, and standard deviation were used. The statistical significance of variables between groups was analyzed using $\mathrm{X}^{2}$ test. A univariate and multivariate analysis was performed to evaluate the association between $25(\mathrm{OH}) \mathrm{D}$ (dependent variables) and other co-factors including (age, sex, marital status, anthropometrics data, sun-light exposure, sun protection factor (SPF), dietary, and supplementary consumption).

Multiple logistic regression analysis was used to ascertain the association between vitamin D deficiency status and its associated risk factors. $P<0.05$ was considered statistically significant.

\section{Results}

A total of 1806 rural subjects including $631(35.0 \%)$ men and 11,75 (65.0\%) women, participated in the study. The characteristics of the participants were shown in Table 1. The subject ages ranged from 23 to 94 years old (mean \pm standard deviation $46 \pm 14$ years). The prevalence of vitamin D deficiency and insufficiency were $28 \%$ (505 subjects), $50 \%$ (913 subjects), respectively. A total of 394 subjects (22\%) had sufficient serum vitamin D levels.

The deficiency of vitamin $\mathrm{D}$ in women was higher than men $(\mathrm{OR}=1.2795 \% \mathrm{CI}$ : 1.05 to $1.54, P=0.04)$. Furthermore, $537(29 \%)$ of the participants $(22 \%$ of women, and $42 \%$ of men) had sun exposure more than $15 \mathrm{~min}$ per-day 2 to 3 times per week. There was a significant difference for mean sun-light exposure among sufficient $(0.82 \pm 1.22 \mathrm{~h}$ per day), insufficient $(0.67 \pm 1.10 \mathrm{~h}$ per day) and deficient $(0.54 \pm 1.02 \mathrm{~h}$ per day) groups of vitamin $\mathrm{D}$ ( $\beta=0.64$ [0.11-1.17], $p=0.016$; Table 1).

The prevalence of consumption of oral calcium, vitamin $\mathrm{D}$, calcium + vitamin $\mathrm{D}$, and parenteral vitamin $\mathrm{D}$ were $37(2 \%), 239(13 \%), 32(2 \%), 7$ (0.4\%), respectively. The negative consumption of tuna and curd was found for a half of the participants, while $72 \%$ of them reported positive consumption of egg. Also, more than $50 \%$ of the participants reported more than the median consumption of dough and milk. Furthermore, 148 $(29 \%)$ and $327(19 \%)$ of the participants reported to have history of hypertension and diabetes mellitus, respectively.

There was also a significant association between age and serum vitamin D levels $(\mathrm{P} \leq 0.001)$.

The rural subjects between 30 and 39 years old and elderly participants of the study with more than 80 years old had the highest and lowest amounts of vitamin D deficiency, respectively.

In men, their serum levels of vitamin D were increased with increasing their age, while by increasing their height, weight, and BMI, it was decreased. However, in women, only age had a positive association with vitamin $\mathrm{D}$ serum levels. In addition, men with vitamin $\mathrm{D}$ deficiency had higher BMI $(P=0.008)$; this association was not observed among women $(P=0.74)$. No association could be found between waist to hip ratio in relation to the status of vitamin D levels $(P>0.05)$ (Table 2). In addition, there was no significant difference between the food items consumption frequencies, and vitamin D status $(P>0.05)$ (Table 3$)$.

In multivariate analysis, sun exposure more than 15 min per-day 2 to 3 times per week (OR=0.93, 95\% CI: 0.88-0.99; $p=0.032)$ and BMI (OR=1.04, $95 \%$ CI:1.04, 
Table 1 The demographic and anthropometric data of the rural population in the northern part of the Persian Gulf

\begin{tabular}{|c|c|c|c|}
\hline Variable & Number (\%) & Variable & Number (\%) \\
\hline Age & & Working outside the room & $596(33.0)$ \\
\hline$<22$ & $12(1.0)$ & The mean of sun exposure (hours per week) & \\
\hline $22-39$ & $653(36.0)$ & $<1 \mathrm{~h}$ & $1241(71.0)$ \\
\hline $40-59$ & $743(41.0)$ & $2-10 h$ & $138(8.0)$ \\
\hline$>60$ & $403(22.0)$ & $11-20 \mathrm{~h}$ & $135(8.0)$ \\
\hline Sex & & $>21 \mathrm{~h}$ & $239(14.0)$ \\
\hline Male & $631(35.0)$ & The sun exposure per week & \\
\hline Female & $1175(65.0)$ & $<5 \min$ & $109(6.0)$ \\
\hline Marital status & & 5-15 min & $347(19.0)$ \\
\hline Single & $184(10.0)$ & $16-30 \mathrm{~min}$ & $370(20.0)$ \\
\hline Married & $1478(82.0)$ & $>30 \min$ & $875(48.0)$ \\
\hline Widow & $120(67.0)$ & Consumption of SPF* & $280(15.0)$ \\
\hline Separated & $22(1.0)$ & Waist circumference (men) & $91(5.0)$ \\
\hline$B M I^{* *}$ & & Waist circumference (women) & $675(37.0)$ \\
\hline Normal & $41(2.0)$ & $W H R^{* * *}$ & \\
\hline Over weight & $690(38.0)$ & $<0.9$ for men & $438(24.0)$ \\
\hline Obese & $106(59.0)$ & $<0.85$ for women & $870(48.0)$ \\
\hline
\end{tabular}

$95 \%$ CI:1.0-1.08; $p=0.017)$ in men, and age (OR=0.98 $95 \%$ CI: $0.97-0.99, p=0.0001)$ in women had significant association with vitamin deficiency status (Table 4).

There was a significant difference between the score of gravidity and vitamin $\mathrm{D}$ status $(P<0.001)$. However, there was no significant association between the months of breast feeding, and serum vitamin D levels $(P=0.2)$. However, 292(46\%) of subjects with vitamin D deficiency, 196 (31\%) of subjects with vitamin D insufficieny, and $143(22 \%)$ of subjects with sufficient serum vitamin $\mathrm{D}$ levels reported that they had history of breast feeding; however, no significant differences could be found among them $(P=0.08)$.

The mountainous, and plain regions of the rural areas had the highest, and lowest vitamin D levels, respectively (Fig. 1).

Table 2 The association among age, anthropometric indices and vitamin D status among rural population of the northern part of the Persian Gulf

\begin{tabular}{|c|c|c|c|c|c|c|c|c|c|c|}
\hline & $\begin{array}{l}\text { Vitamin D } \\
\text { deficient* }\end{array}$ & $\begin{array}{l}\text { Vitamin D } \\
\text { insufficient** }\end{array}$ & $\begin{array}{l}\text { Vitamin D } \\
\text { sufficient }\end{array}$ & Crude $\beta$ & P-Value & $\begin{array}{l}\text { Vitamin D } \\
\text { deficient }\end{array}$ & $\begin{array}{l}\text { Vitamin D } \\
\text { insufficient }\end{array}$ & $\begin{array}{l}\text { Vitamin D } \\
\text { sufficient }\end{array}$ & Crude $\beta$ & P-Value \\
\hline & Male & & & & & Female & & & & \\
\hline Age & 46. \pm 15 & 47. \pm 14 & $50 \pm 16$ & $\begin{array}{l}0.05(0.00 \\
\text { to } 0.11)\end{array}$ & 0.043 & 44. \pm 13 & $47 \pm 14$ & $48 \pm 14$ & $\begin{array}{l}0.11(0.06 \\
\text { to } 0.16)\end{array}$ & 0.0001 \\
\hline Height & 170. \pm 7 & $170 \pm 7.3$ & $170 \pm 7$ & $\begin{array}{l}-0.11(-0.02 \\
\text { to } 0.00)\end{array}$ & 0.048 & $160 \pm 11$ & $160 \pm 14$ & $160 \pm 8$ & $\begin{array}{l}0.00(-0.05 \\
\text { to } 0.06)\end{array}$ & 0.86 \\
\hline Weight & $76 \pm 15$ & 73. \pm 14 & $70 . \pm 11$ & $\begin{array}{l}-0.09(-0.15 \\
\text { to }-0.03)\end{array}$ & 0.002 & $67 \pm 14$ & $68 \pm 14$ & 66. \pm 14 & $\begin{array}{l}-0.03(-0.09 \\
\text { to } 0.01)\end{array}$ & 0.13 \\
\hline $\begin{array}{l}\text { Body mass } \\
\text { index }\end{array}$ & $26 \pm 4.7$ & 25. \pm 4.3 & $25 \pm 3.4$ & $\begin{array}{l}-0.25(-0.45 \\
\text { to }-0.06)\end{array}$ & 0.01 & 27. \pm 5.4 & 28. \pm 5.7 & $27 . \pm 6.0$ & $\begin{array}{l}-0.08(-0.21 \\
\text { to } 0.04)\end{array}$ & 0.19 \\
\hline $\begin{array}{l}\text { Waist } \\
\text { circumference }\end{array}$ & $91 . \pm 17$ & $90 \pm 17$ & $89 \pm 14$ & $\begin{array}{l}-0.02(-0.07 \\
\text { to } 0.03)\end{array}$ & 0.42 & $90 . \pm 17$ & $91 \pm 17$ & $89 \pm 20$ & $\begin{array}{l}-0.02(-0.06 \\
\text { to } 0.01)\end{array}$ & 0.29 \\
\hline $\begin{array}{l}\text { Hip } \\
\text { circumference }\end{array}$ & $98 \pm 17$ & $97 \pm 17$ & $95 \pm 15$ & $\begin{array}{l}-0.03(-0.08 \\
\text { to } 0.01)\end{array}$ & 0.19 & 100. \pm 18 & $100 \pm 20$ & $99 . \pm 21$ & $\begin{array}{l}0.09(-0.04 \\
\text { to } 0.02)\end{array}$ & 0.60 \\
\hline
\end{tabular}

* Serum 25(OH)D levels of $<20 \mathrm{ng} / \mathrm{ml}$

**Serum 25(OH)D levels between $20-<30 \mathrm{ng} / \mathrm{ml}$

*** Serum 25(OH)D levels between 30-100 ng/ml 
Table 3 The nutritional consumption of food items across vitamin D groups among rural population of the northern part of the Persian Gulf

\begin{tabular}{|c|c|c|c|c|}
\hline Variable & $\begin{array}{l}\text { Vitamin D deficient } \\
(<20 \mathrm{ng} / \mathrm{ml})\end{array}$ & $\begin{array}{l}\text { Vitamin D insufficient } \\
(20-<30 \mathrm{ng} / \mathrm{ml})\end{array}$ & $\begin{array}{l}\text { Vitamin D sufficient } \\
(30-100 \mathrm{ng} / \mathrm{ml})\end{array}$ & $P$ value \\
\hline $\begin{array}{l}\text { Egg consumption } \\
\text { (grams per day) }\end{array}$ & $24 . \pm 19$ & $24 . \pm 32$ & $23 \pm 19$ & 0.39 \\
\hline $\begin{array}{l}\text { Fish consumption } \\
\text { (grams per day) }\end{array}$ & $25 . \pm 22$ & 23. \pm 20 & 23. \pm 20 & 0.09 \\
\hline $\begin{array}{l}\text { Tuna consumption } \\
\text { (grams per day) }\end{array}$ & $1.2 \pm 3.7$ & $1.1 \pm 3.2$ & $1.00 \pm 3.2$ & 0.48 \\
\hline $\begin{array}{l}\text { Milk consumption } \\
\text { (grams per day) }\end{array}$ & 76. \pm 95 & $80 . \pm 120$ & 76. \pm 100 & 0.79 \\
\hline $\begin{array}{l}\text { Cheese consumption } \\
\text { (grams per day) }\end{array}$ & 18. \pm 18 & $18 . \pm 17$ & 17. \pm 20 & 0.92 \\
\hline $\begin{array}{l}\text { Dough consumption } \\
\text { (grams per day) }\end{array}$ & $130 \pm 110$ & $130 \pm 110$ & $130 \pm 130$ & 0.95 \\
\hline $\begin{array}{l}\text { Curd consumption } \\
\text { (grams per day) }\end{array}$ & $3.2 \pm 6.4$ & $30.0 \pm 9.0$ & 3. \pm 10 & 0.80 \\
\hline
\end{tabular}

\section{Discussion}

In this population-based study which was done in all rural districts of Bushehr province, it was shown that a half of the rural participants had vitamin D deficiency, more than one to five of the participants had vitamin D insufficiency, and one to five of total population had sufficient vitamin D levels.

Unfortunately, there are limited studies on rural population in Iran regarding vitamin D levels, and most of the studies have been done on the capital cities; therefore, it is impossible to compare vitamin D serum levels of rural and urban populations. The only study that evaluated the Iranian rural and urban populations was done on Guilan province which compared 750 postmenopausal women in rural and urban areas and demonstrated that vitamin $\mathrm{D}$ deficiency was more common in urban than rural subjects [25]. This difference among rural and urban subjects was also observed in other countries [26]. In a systematic review and meta-analysis study in Africa it was shown that the mean of serum vitamin $\mathrm{D}$ levels in urban places was less than the rural areas [27]. This difference could be explained with different lifestyles, jobs, and habitual conditions because the rural inhabitants live more outdoor and expose to more sun-light, resulting with more absorption of vitamin D by their skin; in another aspect, the urban lifestyle patterns cause less amount of vitamin D absorption via sun-light exposure or less amount of dietary vitamin D intake through food habits [25, 27].

Although, in the current study, we could not compare the prevalence of vitamin D deficiency in urban and rural regions, we found that the prevalence of vitamin $\mathrm{D}$ deficiency in rural areas was at least similar to those prevalence rates that has been reported from Bushehr city (the capital of Bushehr province), the middle east and south east of Asia, and China [19, 28-30]. In two systematic reviews and meta-analyses from Iran, it was reported that more than a half of the Iranian population, especially those who live in capital cities, had vitamin D deficiency [23, 24].

In Iran, the fundamental infrastructural and economical changes during the post 1979 revolution produced a trend in rural areas to adopt the behaviors, values, attitudes, and traditions of urbanism. This transformation

Table 4 Multivariate adjusted odds ratios (OR) and $95 \%$ confidence intervals relating vitamin D deficiency status and its associated risk factors among rural population of the northern part of the Persian Gulf

\begin{tabular}{|c|c|c|c|c|c|c|}
\hline \multirow[b]{3}{*}{ Variable } & \multicolumn{3}{|c|}{ Vitamin D deficiency } & \multicolumn{3}{|c|}{ Vitamin D deficiency } \\
\hline & Male & & & Fema & & \\
\hline & OR & $95 \% \mathrm{Cl}$ & P-Value & OR & $95 \% \mathrm{Cl}$ & P-Value \\
\hline Age & 0.99 & 0.97 to 1.00 & 0.096 & 0.98 & 0.97 to 0.99 & 0.0001 \\
\hline sun exposure more than 15 min per-day 2 to 3 times per week & 0.93 & 0.88 to 0.99 & 0.032 & 0.95 & 0.90 to 1.00 & 0.059 \\
\hline Taking vitamin D supplements & 0.84 & 0.53 to 1.33 & 0.481 & 1.09 & 0.81 to 1.47 & 0.539 \\
\hline Marital Status & 1.22 & 0.77 to 1.94 & 0.389 & 0.96 & 0.76 to 1.20 & 0.733 \\
\hline Body Mass Index & 1.04 & 1.00 to 1.08 & 0.017 & 0.99 & 0.97 to 1.01 & 0.570 \\
\hline
\end{tabular}




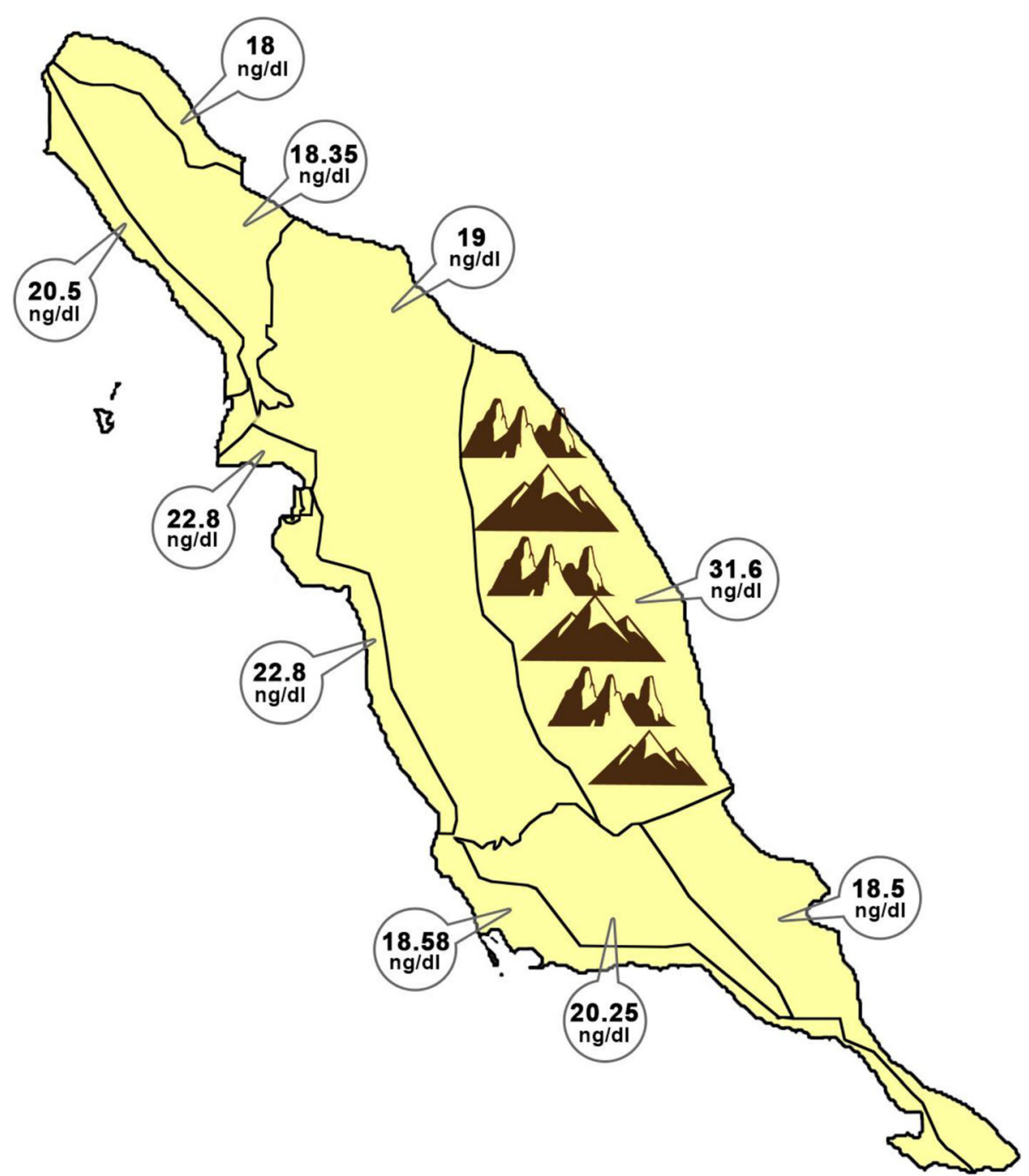

Fig. 1 The age-adjusted medians of serum vitamin D levels in the mountainous and plain regions of the rural areas of the northern part of the Persian Gulf

created a change of lifestyle from rural to urban patterns including consumerism, employment in non-agricultural jobs and activities [31].

The transformation of people's lifestyles along with changes in living conditions and settlement models from rural to urban promoted an unhealthy lifestyle in the northern Persian Gulf region. We assessed prevalence of unhealthy lifestyles in 3723 participants aged $>$ or $=25$ years in this region; over $60 \%$ had unhealthy body weight, only $8.3 \%$ ate the recommended amount of fruits and vegetables, $70.6 \%$ were physically inactive [32]. Therefore, the adoption of an unhealthier lifestyle accompanied with more indoor activities and lower sun exposure by the rural population of the northern Persian Gulf region may have induced their mean vitamin D serum levels to approach to their urban counterparts.
In our study, we found a linear relationship between serum vitamin $\mathrm{D}$ levels and sun-light exposure. In the European population, it has been revealed that sun exposure of $18 \%$ of body surface area for $15 \mathrm{~min}$ per-day, 2 to 3 times per week is sufficient for absorbing vitamin D [33]. However, in the current study, only $29 \%$ of participant had fulfilled the above criteria. This low level of sun-exposure in the rural areas may be due to the mentioned changes of lifestyle towards the urban patterns. The cultural factors may also have an effect on the amount of villager's sun-light exposure because of the types of their clothing which cover their arms and legs for all seasons.

The effect of body coverage on circulating vitamin D is so important that in sunny countries such as Saudi Arabia and the United Arab Emirates, a high prevalence 
of vitamin D deficiency could be found; likewise, in Iranian sunny cities such as Zahedan and Isfahan, a high vitamin D deficiency have been reported [34-37].

In another aspect, the effect of sun exposure on vitamin D serum levels could be ascribed by its seasonal patterns of sun-light exposure; in winter, we can expect to obtain less amount of vitamin $\mathrm{D}$ by decreasing in sun-light exposure [37]. In the current study, all the serum samples were obtained during winter; therefore, the effect of seasonal patterns could not be evaluated. However, it seems that there is a complex interaction between the effect of season and bio-cultural factors.

Surprising, the mean serum vitamin D was highest in winter and lowest in the summer in a sunny country like the United Arab Emirates [34]. The climate of the United Arab Emirate is very similar to Bushehr province in the northern parts of the Persian Gulf. It could be postulated that the high temperature of these places induces people live most of their times indoor to escape the hot condition during summer times. Hence, they receive less amounts of sun-light exposure, leading to the lowest range of serum vitamin D levels during summer. In order to elucidate the complex interaction of cultural, and bio-environmental factors on circulate vitamin D levels, more studies during different seasons are warranted.

In this study, an association between vitamin $\mathrm{D}$ serum levels and age was found. It was interesting that the minimum serum levels of vitamin D were observed in 30 to 39 years old age group; and surprisingly the highest levels of vitamin D were found among rural subjects who had more than 80 years old. In an Iranian metaanalysis the highest prevalence for vitamin $\mathrm{D}$ deficiency was found among the 20 to 50 years old age group [24]. In contrast, in a previous study, children and elder people had the highest prevalence of vitamin D deficiency [38]. In Iran, due to not including older people in the previous population based studies about the prevalence of vitamin D deficiency, a comparison would not be possible [23].

The consumption of multivitamins and vitamin D pills by the elderly may lead to a lower prevalence of vitamin $\mathrm{D}$ in this age group in comparison to the younger participant in our study. Another contributing factor for this difference may be the changes of life styles of younger people that induce them to choose living and working indoor places with resulting in less sun-light exposure. In consistent with our finding, a positive correlation between age and vitamin D serum levels was found in Zahedan city (the capital of Sistan, and Balochestan province in the south east of Iran) [23, 24]. Likewise, the younger age group had a higher prevalence of vitamin $\mathrm{D}$ deficiency than older age group in Isfahan city ( the capital of Isfahan province in the center of Iran)
[37]. Taken together, the change of lifestyle patterns and the trend of younger people to stay in indoor places, and living in apartments may explain this difference for prevalence of vitamin $\mathrm{D}$ deficiency among different age groups.

In our study, the prevalence of vitamin D deficiency was more common in men than women. The results of two meta-analyses studies from Iran showed that the prevalence of vitamin D deficiency, like other Asian countries, was more common in women than men [23, 24]. In a trend prevalence study of vitamin D deficiency during 1990-2010 in Iran, it was also reported that women gained a higher vitamin $\mathrm{D}$ deficiency than men year-over-year[39].

There are contradictory results about vitamin D deficiency in relation to sex in the world. In contrast to a previous study in America, no difference could be found between sex groups in relation to vitamin D deficiency in NHANES 2001-2004 [40]; but, in a later study in America, women had a higher vitamin D levels than men [41]. In Africa, the prevalence of vitamin D deficiency was higher in women than men [27]. In the United Arab Emirates (UAE), the prevalence of vitamin $\mathrm{D}$ deficiency was similar in both sexes [42]. It has been suggested that cultural and religious factors might be the causative factors for the observed higher prevalence of vitamin D among Muslims women; for instance, in Lebanon, the Muslim women had lower vitamin D serum levels than the Christian women [43]. These contradictory results indicate that other contributing factors beyond veiling should be considered to explain this difference.

Obesity is another condition that has a connection both to the patterns of life style and vitamin D serum levels [44]. In many epidemiological studies from tropical countries, a negative significant association between obesity and serum 25(OH)D levels were reported after controlling for potential confounders [45-47]. According to the results of a meta-analysis, that investigated relationship between obesity and vitamin D deficiency, a higher prevalence of vitamin D deficiency was found among obese subjects independent to traditional risk factors including the Human Development Index of the study location [48]. Interestingly, in another systematic review and meta-analysis of randomized controlled trials, it was reported that obesity in adults attenuated the effect of vitamin D supplementation [49]. The body fat content has a reverse correlation with vitamin D concentration. This inverse correlation may be due to the decrease bio-availability of vitamin D3 from dietary sources and skin because of the deposition of vitamin D in body fat compartments [50]; even the elder subjects with high body fat and higher body mass index have lower levels of $25(\mathrm{OH}) \mathrm{D}$ levels [51]. Other factors 
contribute to the inverse relationship between body mass index and vitamin D levels, such as decreased mobility in obese people, which reduces their exposure to sunlight [44].

In our study, men with vitamin $\mathrm{D}$ deficiency had a higher anthropometric index (BMI) than men with sufficient vitamin D levels, while no difference was observed between the two groups in women; therefore, other contributing factors beyond obesity should be considered that modify the effect of obesity, such as intake of vitamin D supplements and the number of pregnancies.

Although the current study is one of the largest studies that investigated vitamin D deficiency in the Iranian rural subjects, it has some limitations. One of these limitations is non-repetition of measurements for vitamin D levels during different seasons. The physical activity, and their smoking status of the participants were not also assessed. However, the evaluation of nutritional status as well as sun exposure which were addressed in this study could be ascribed as one of its strengths.

Another strength of the study is its design so that the effect of the latitude (mountainous, plain and coastal places) of living areas on the level of vitamin $\mathrm{D}$ could be evaluated. In this study, the northern half part of the rural mountainous area of Bushehr province had a higher mean of vitamin D level than the plains and coastal areas. There was no significant difference in daily consumption of dairy, and milk products between mountainous area, and other parts of this province. This difference may be partly originated from the altitude effect (AE) on solar radiation intensity because UV B photons undergo less scattering and absorption by traversing the thinner atmosphere of the mountainous areas. The resulting effect will be sufficient exposure to UV B for synthesis of more vitamin D in the epidermis of the mountain dwellers than the plain dwellers. Although we did not assess the level of air pollution in different geographical areas in this study, it has been shown that air pollution levels including many organic aerosols have a significant reduction in UV spectral irradiances [52-54].

By considering widespread vitamin deficiency in all age groups and that natural sources of vitamin $\mathrm{D}$ cannot maintain circulating $25(\mathrm{OH}) \mathrm{D}$ levels in the recommended target of 30-50 $\mathrm{ng} / \mathrm{ml}(75-125 \mathrm{nmol} / \mathrm{L})$, systemic vitamin $\mathrm{D}$ food fortification and targeted vitamin D supplementation may be suggested as effective strategies in order to combat with vitamin $\mathrm{D}$ deficiency $[55,56]$. These strategies have been considered in Asian countries [15], US, Canada and Finland [57]. In India, the programs of enrichment of a dietary source with vitamin $\mathrm{D}$, supplementation of vitamin D plus calcium, and inclusion of local fortified food items were launched by local governmental agencies, and other state holders [58]. It has been shown in a modelling study that fortifying at least one food vehicle (edible plant-based oil, wheat flour and milk) can increase per capita vitamin $\mathrm{D}$ supply to maintain serum $25(\mathrm{OH}) \mathrm{D} \geq 25 \mathrm{nmol} / \mathrm{L}$ in low/lowermiddle income countries [59]. An individual-level simulation model revealed cost effectiveness of the combined strategy of wheat flour fortification and targeted vitamin D supplementation [60].

In Iran, a community-based interventional trial of vitamin D fortified milk has been started [61]. The results of this trial could be applied in different parts of the country to tackle vitamin D deficiency in the near future. However, it is important to incorporate coverage for processing, storage, and cooking in fortification processes . Otherwise, the effectiveness of fortification may be diminished considerably, particularly in the case of less stable vitamins. Therefore, considering multiple fortification vehicles for delivery of the same and different nutrients is prudent, as it may increase the overall effectiveness of fortification and allow natural variation in population dietary patterns to be exploited for more effective targeting of intake deficiencies in different subgroups [62].

The supplementation of vitamin $\mathrm{D}$ has been suggested as a safe and effective way to tackle vitamin D deficiency [55]. The intake of vitamin D supplements were reported to be low in Iran $[23,63]$. In the current study, only $16 \%$ of participants reported taking vitamin D or calcium plus vitamin D supplements. Since vitamin D is crucial for preventing of several chronic, communicable and non-communicable diseases[55], the development of vitamin D supplementation should be considered as an national need to meet its requirements.

\section{Conclusions}

Although, Bushehr province is located in a sunny part of Iran, our study showed that there is a high prevalence of vitamin $\mathrm{D}$ deficiency among the rural population of $\mathrm{Bu}-$ shehr province. This prevalence is similar to those prevalence rates that have been reported from the urban areas of Iran. This similarity of prevalence may be partly due to the shift of the rural dwellers life styles patterns that originated from the rapid industrialization development in these rural areas.

\section{Abbreviations \\ BMI: Body mass index; ELISA: enzyme-linked immunosorbent assay; IMOS: Iranian Multi-Centric Osteoporosis Studies; BUMS: Bushehr University of Medical Science; UK: United Kingdom; KS-test: The Kolmogorov-Smirnov test; SPF: sun protection factor; NHANES: National Health and Nutrition Examination Survey; UAE: United Arab Emirates}

\section{Acknowledgements}

We wish to thank staff of Bushehr province Health Affairs for their kind assistance in the research field. We are in debated to Zahra Sanjdideh for her kind assistance in laboratory management. 


\section{Authors' contributions}

$\mathrm{MM}, \mathrm{IN}, \mathrm{AO}$ conceived the study and performed data analysis and interpretation. MK, MEM, and AA drafted the manuscript and participated in interpretation, study design and conduct and helped draft the manuscript and interpretation.SK, AKH, AHD, and $\mathrm{AB}$ participated in the study design and interpretation of the findings. All authors reviewed and approved the submitted manuscript.

\section{Funding}

Research reported in this publication was supported by Elite Researcher Grant Committee under award number [958380] from the National Institute for Medical Research Development (NIMAD), Tehran, Iran.

\section{Availability of data and materials}

The datasets used and/or analyzed during the current study are available from the corresponding author on reasonable request.

\section{Declarations}

\section{Ethics approval and consent to participate}

This study was conducted in agreement with the declaration of Helsinki and Iranian national guidelines for ethics in research. Written informed consent was obtained from all participants prior to study enrolment. Participation was voluntary and each participant could withdraw consent at any time without any consequence. Data collected are stored in a re-identifiable form by national id code. The study was approve in the ethical committee by a grant from National Institute for Medical Research Development (NIMAD)

\section{Consent for publication}

Not applicable.

\section{Competing interests}

The authors declare they have no conflict of interest.

\section{Author details}

'The Persian Gulf Tropical Medicine Research Center, The Persian Gulf Biomedical Sciences Research Institute, Bushehr University of Medical Sciences, Bushehr, Iran. ${ }^{2}$ Department of Endocrine and Metabolic Disease, the Persian Gulf Tropical Medicine Research Center, Bushehr University of Medical Sciences, Bushehr, Iran. ${ }^{3}$ Osteoporosis Research Center, Endocrinology and Metabolism Clinical Sciences Institute, Tehran University of Medical Sciences, Tehran, Iran. ${ }^{4}$ Faculty of Medicine, Bushehr University of Medical Sciences, Bushehr, Iran. ${ }^{5}$ Faculty of health, Bushehr University of Medical Sciences, Bushehr, Iran. ${ }^{6}$ Department of Internal Medicine, Division of Rheumatology, School of Medicine, Bushehr University of Medical Sciences, Bushehr, Iran.

Received: 15 November 2020 Accepted: 18 October 2021 Published online: 03 November 2021

\section{References}

1. Autier P, Boniol M, Pizot C, Mullie P. Vitamin D status and ill health: a systematic review. The lancet Diabetes \& endocrinology. 2014;2(1):76-89.

2. Liu X, Baylin A, Levy PD. Vitamin D deficiency and insufficiency among US adults: prevalence, predictors and clinical implications. British Journal of Nutrition. 2018;119(8):928-36.

3. Holick MF. Vitamin D deficiency. New England Journal of Medicine. 2007; 357(3):266-81.

4. Brenner H, Jansen L, Saum K-U, Holleczek B, Schöttker B. Vitamin D supplementation trials aimed at reducing mortality have much higher power when focusing on people with low serum 25-hydroxyvitamin D concentrations. The Journal of nutrition. 2017;147(7):1325-33.

5. Acharya P, Dalia T, Ranka S, Sethi P, Oni OA, Safarova MS, Parashara D, Gupta K, Barua RS. The Effects of Vitamin D Supplementation and 25Hydroxyvitamin D Levels on the Risk of Myocardial Infarction and Mortality. Journal of the Endocrine Society. 2021;5(10):bvab124

6. Anderson JL, May HT, Horne BD, Bair TL, Hall NL, Carlquist JF, Lappé DL, Muhlestein JB, Group IHCIS. Relation of vitamin D deficiency to cardiovascular risk factors, disease status, and incident events in a general healthcare population. The American journal of cardiology. 2010;106(7):963-8.
7. Ginde AA, Scragg R, Schwartz RS, Camargo CA Jr. Prospective study of serum 25-hydroxyvitamin D level, cardiovascular disease mortality, and allcause mortality in older US adults. Journal of the American Geriatrics Society. 2009;57(9):1595-603.

8. Song D, Deng Y, Liu K, Zhou L, Li N, Zheng Y, Hao Q, Yang S, Wu Y, Zhai Z. Vitamin D intake, blood vitamin D levels, and the risk of breast cancer: a dose-response meta-analysis of observational studies. Aging (Albany NY). 2019;11(24):12708

9. McCullough ML, Zoltick ES, Weinstein SJ, Fedirko V, Wang M, Cook NR, Eliassen AH, Zeleniuch-Jacquotte A, Agnoli C, Albanes D. Circulating vitamin $\mathrm{D}$ and colorectal cancer risk: an international pooling project of 17 cohorts. JNCl: Journal of the National Cancer Institute. 2019;111(2):158-69.

10. Park SK, Garland CF, Gorham ED, BuDoff L, Barrett-Connor E. Plasma 25hydroxyvitamin $\mathrm{D}$ concentration and risk of type 2 diabetes and prediabetes: 12-year cohort study. PloS one. 2018;13(4):e0193070.

11. Dawson-Hughes B, Staten MA, Knowler WC, Nelson J, Vickery EM, LeBlanc ES, Neff LM, Park J, Pittas AG: Intratrial exposure to vitamin D and new-onset diabetes among adults with prediabetes: a secondary analysis from the vitamin D and type 2 diabetes (D2d) study. Diabetes Care 2020, 43(12):29162922

12. Martineau AR, Jolliffe DA, Hooper RL, Greenberg L, Aloia JF, Bergman $P$, Dubnov-Raz G, Esposito S, Ganmaa D, Ginde AA: Vitamin D supplementation to prevent acute respiratory tract infections: systematic review and meta-analysis of individual participant data. bmj 2017, 356

13. Kaufman HW, Niles JK, Kroll MH, Bi C, Holick MF. SARS-CoV-2 positivity rates associated with circulating 25-hydroxyvitamin D levels. PloS one. 2020;15(9): e0239252.

14. Holick MF: High prevalence of vitamin D inadequacy and implications for health. In: Mayo Clinic Proceedings: 2006: Elsevier; 2006: 353-373.

15. Malhotra N, Mithal A. Vitamin D status in Asia. International Osteoporosis Foundation. 2009;2009:1-3.

16. Lips P. Vitamin D status and nutrition in Europe and Asia. The Journal of steroid biochemistry and molecular biology. 2007;103(3-5):620-5.

17. Looker AC, Johnson CL, Lacher DA, Pfeiffer CM, Schleicher RL, Sempos CT: Vitamin D status: United states, 2001-2006. NCHS data brief 2011, 59(59):1-8.

18. Knutsen KV, Brekke M, Gjelstad S, Lagerløv P. Vitamin D status in patients with musculoskeletal pain, fatigue and headache: a cross-sectional descriptive study in a multi-ethnic general practice in Norway. Scandinavian journal of primary health care. 2010;28(3):166-71.

19. Heshmat R, Mohammad K, Majdzadeh S, Forouzanfar M, Bahrami A, Ranjbar Omrani G, Nabipour I, Rajabian R, Hossein-Nezhad A, Rezaei Hemami M. Vitamin $D$ deficiency in Iran: A multi-center study among different urban areas. Iran J Public Health. 2008:37(1):72-8.

20. Moradzadeh K, Larijani B, Keshtkar A, Hossein-Nezhad A, Rajabian R, Nabipour I, Omrani G, Bahrami A, Gooya M, Delavari A. Normative values of vitamin D among Iranian population: a population based study. International journal of osteoporosis \& metabolic disorders. 2008;1(1):8-15.

21. Farhud DD, Mehrabi A, Sarafnejad A, Sadeghipour HR, Rahimiforoushani A, Rokni MB, Majidi K, Alizadeh A, Zarif-Yeganeh M, Jalali M. A Comprehensive, Epidemiological and Ecological Descriptive Study on Vitamin D Status in Iran (308005 People, from 2009-2018). Iranian Journal of Public Health. 2019;48(4):644.

22. Agarwal K, Mughal M, Upadhyay P, Berry J, Mawer E, Puliyel J. The impact of atmospheric pollution on vitamin D status of infants and toddlers in Delhi, India. Archives of disease in childhood. 2002;87(2):111-3.

23. Tabrizi R, Moosazadeh M, Akbari M, Dabbaghmanesh MH, Mohamadkhani M, Asemi Z, Heydari ST, Akbari M, Lankarani KB. High prevalence of vitamin $D$ deficiency among Iranian population: a systematic review and metaanalysis. Iranian journal of medical sciences. 2018;43(2):125.

24. Vatandost S, Jahani M, Afshari A, Amiri MR, Heidarimoghadam R, Mohammadi Y: Prevalence of vitamin D deficiency in Iran: a systematic review and meta-analysis. Nutrition and health 2018, 24(4):269-278.

25. Maddah M, Sharami SH, Neyestani TR. Vitamin D insufficiency among postmenopausal women in urban and rural areas in Guilan, Northern Iran. Journal of Nutrition for the Elderly. 2009;28(4):386-93.

26. Gu W, Rennie $K L$, Lin $X$, Wang $Y, Y u Z$. Differences in bone mineral status between urban and rural Chinese men and women. Bone. 2007:41(3):393-9.

27. Mogire RM, Mutua A, Kimita W, Kamau A, Bejon P, Pettifor JM, Adeyemo A, Williams TN, Atkinson SH. Prevalence of vitamin D deficiency in Africa: a systematic review and meta-analysis. The Lancet Global Health. 2020;8(1): e134-42. 
28. Malhotra N, Mithal A: Vitamin D status in Asia. International Osteoporosis Foundation. 2009. In.; 2018.

29. Lips P, Cashman KD, Lamberg-Allardt C, Bischoff-Ferrari HA, ObermayerPietsch B, Bianchi ML, Stepan J, Fuleihan GE-H, Bouillon R. Current vitamin D status in European and Middle East countries and strategies to prevent vitamin D deficiency: a position statement of the European Calcified Tissue Society. European Journal of Endocrinology. 2019;180(4):P23-54.

30. Malacova E, Cheang PR, Dunlop E, Sherriff JL, Lucas RM, Daly RM, Nowson $C A, B$ lack $L$. Prevalence and predictors of vitamin $D$ deficiency in a nationally representative sample of adults participating in the 2011-2013 Australian Health Survey. The British journal of nutrition. 2019;121(8):894904.

31. asghar Pilehvar A. Spatial-geographical analysis of urbanization in Iran. Humanities and Social Sciences Communications. 2021:8(1):1-12.

32. Nabipour I, Amiri M, Imami S, Jahfari S, Nosrati A, Iranpour D, Soltanian A: Unhealthy lifestyles and ischaemic electrocardiographic abnormalities: the Persian Gulf Healthy Heart Study. EMHJ-Eastern Mediterranean Health Journal, 14 (4), 858-868, 20082008.

33. Holick MF: Photosynthesis of vitamin D in the skin: effect of environmental and life-style variables. In: Federation proceedings: 1987; 1987: 1876.

34. Al Zarooni AAR, Al Marzouqi Fl, Al Darmaki SH, Prinsloo EAM, Nagelkerke N. Prevalence of vitamin D deficiency and associated comorbidities among Abu Dhabi Emirates population. BMC research notes. 2019;12(1):1-6.

35. Elsammak M, Al-Wossaibi A, Al-Howeish A, Alsaeed J: High prevalence of vitamin D deficiency in the sunny Eastern region of Saudi Arabia: a hospitalbased study. Eastern Mediterranean Health Journal 2011, 17(4).

36. Kaykhaei MA, Hashemi M, Narouie B, Shikhzadeh A, Rashidi H, Moulaei N, Ghavami S. High prevalence of vitamin D deficiency in Zahedan, southeast Iran. Annals of Nutrition and Metabolism. 2011;58(1):37-41.

37. Hovsepian S, Amini M, Aminorroaya A, Amini P, Iraj B. Prevalence of vitamin D deficiency among adult population of Isfahan City, Iran. Journal of health, population, and nutrition. 2011;29(2):149.

38. Hilger J, Friedel A, Herr R, Rausch T, Roos F, Wahl DA, Pierroz DD, Weber P, Hoffmann K. A systematic review of vitamin D status in populations worldwide. British journal of nutrition. 2014;111(1):23-45.

39. Asadinia Arezoo BL, Shirin Jalalinia Farshad, Farzadfar AbbasAli, Keshtkar. Ehsan Rezai, Iraj Esmaili: The prevalence of vitamin D deficiency among Iranian population during 1990-2010. Iranian Diabete and Metabolism. 2011; 16:574-84.

40. Ginde AA, Liu MC, Camargo CA: Demographic differences and trends of vitamin D insufficiency in the US population, 1988-2004. Archives of internal medicine 2009, 169(6):626-632.

41. Mitchell D, Henao M, Finkelstein J, Burnett-Bowie S-A. Prevalence and predictors of vitamin D deficiency in healthy adults. Endocrine Practice. 2012;18(6):914-23.

42. Al Zarooni AAR, Al Marzouqi FI, Al Darmaki SH, Prinsloo EAM, Nagelkerke N. Prevalence of vitamin D deficiency and associated comorbidities among Abu Dhabi Emirates population. BMC research notes. 2019;12(1):503.

43. Gannage-Yared M-H, Maalouf G, Khalife S, Challita S, Yaghi Y, Ziade N, Chalfoun A, Norquist J, Chandler J. Prevalence and predictors of vitamin D inadequacy amongst Lebanese osteoporotic women. British Journal of Nutrition. 2008;101(4):487-91.

44. Parva NR, Tadepalli S, Singh P, Qian A, Joshi R, Kandala H, Nookala VK, Cheriyath P: Prevalence of vitamin D deficiency and associated risk factors in the US population (2011-2012). Cureus 2018, 10(6).

45. Shafinaz I, Moy F. Vitamin D level and its association with adiposity among multi-ethnic adults in Kuala Lumpur, Malaysia: a cross sectional study. BMC public health. 2016;16(1):1-9.

46. Wakayo T, Belachew T, Vatanparast $H$, Whiting SJ. Vitamin D deficiency and its predictors in a country with thirteen months of sunshine: the case of school children in central Ethiopia. PloS one. 2015;10(3):e0120963.

47. Pan T, Banerjee R, Dasgupta A, Paul B. Vitamin D status among women aged 40 years and above in a rural area of West Bengal: A communitybased study. Journal of family medicine and primary care. 2018;7(6):1263.

48. Pereira-Santos M, Costa PdF, Ad Assis. Santos CdS, Santos Dd: Obesity and vitamin D deficiency: a systematic review and meta-analysis. Obesity reviews. 2015;16(4):341-9.

49. de Oliveira LF, de Azevedo LG, da Mota Santana J, de Sales LPC, PereiraSantos M. Obesity and overweight decreases the effect of vitamin D supplementation in adults: systematic review and meta-analysis of randomized controlled trials. Reviews in Endocrine and Metabolic Disorders. 2020;21(1):67-76.

50. Vitezova A, Muka T, Zillikens MC, Voortman T, Uitterlinden AG, Hofman A, Rivadeneira F, Kiefte-de Jong JC, Franco OH. Vitamin D and body composition in the elderly. Clinical Nutrition. 2017;36(2):585-92.

51. Suryanarayana P, Arlappa N, Sai Santhosh V, Balakrishna N, Lakshmi Rajkumar P, Prasad U, Raju BB, Shivakeseva K, Divya Shoshanni K, Seshacharyulu M. Prevalence of vitamin D deficiency and its associated factors among the urban elderly population in Hyderabad metropolitan city, South India. Annals of Human Biology. 2018;45(2):133-9.

52. Ambach $W$, Blumthaler $M$, Wendler $G$. A comparison of ultraviolet radiation measured at an arctic and an alpine site. Solar Energy. 1991;47:121-126.

53. McKenzie R, Weinreis C, Johnston P, Liley B, Shiona H, Kotkamp M, Smale D, Takegawa N, Kondo Y. Effects of urban pollution on UV spectral irradiances. Atmospheric Chemistry and Physics. 2008;8(18):5683-97.

54. Blumthaler $M$, Ambach W, Ellinger R. Increase in solar UV radiation with altitude. Journal of Photochemistry and Photobiology B: Biology 1997;39: 130-134

55. Pludowski P, Holick MF, Grant WB, Konstantynowicz J, Mascarenhas MR, Haq A, Povoroznyuk V, Balatska N, Barbosa AP, Karonova T. Vitamin D supplementation guidelines. J Steroid Biochem Mol Biol. 2018;175:125-35.

56. Holick MF, Binkley NC, Bischoff-Ferrari HA, Gordon CM, Hanley DA, Heaney $\mathrm{RP}$, Murad MH, Weaver CM. Evaluation, treatment, and prevention of vitamin D deficiency: an Endocrine Society clinical practice guideline. J Clin Endocrinol Metab. 2011:96(7):1911-30.

57. 57. Pilz S, März W, Cashman KD, Kiely ME, Whiting SJ, Holick MF, Grant WB, Pludowski P, Hiligsmann M, Trummer C. Rationale and plan for vitamin D food fortification: a review and guidance paper. Front Endocrinol. 2018;9: 373.

58. Kamboj P, Dwivedi S, Toteja G. Prevalence of hypovitaminosis D in India \& way forward. Indian J Med Res. 2018;148(5):548.

59. Cashman KD, O'Dea R. Exploration of strategic food vehicles for vitamin D fortification in low/lower-middle income countries. J Steroid Biochem Mol Biol. 2019;195:105479.

60. Aguiar M, Andronis L, Pallan M, Högler W, Frew E. The economic case for prevention of population vitamin D deficiency: a modelling study using data from England and Wales. Eur J Clin Nutr. 2020;74(5):825-33.

61. Keshtkar A, Ebrahimi M, Khashayar P, Abdollahi Z, Porarram H, Salehi F, Mohammadi Z, Khosrokhavar R, Larijani B. Community interventional trial (CITFOMIST) of vitamin D fortified versus non-fortified milk on serum levels of $25(\mathrm{OH}) \mathrm{D}$ in the students of Tehran. Arch Iran Med. 2015;18(5).

62. Bromage S, Ganmaa D, Rich-Edwards JW, Rosner B, Bater J, Fawzi WW. Projected effectiveness of mandatory industrial fortification of wheat flour, milk, and edible oil with multiple micronutrients among Mongolian adults. PloS One. 2018;13(8):e0201230.

63. Maddah M, Sharami SH. Intake of calcium/vitamin D supplement in Iranian postmenopausal women. Arch Osteoporos. 2009;4(1):95-96.

\section{Publisher's Note}

Springer Nature remains neutral with regard to jurisdictional claims in published maps and institutional affiliations.

Ready to submit your research? Choose BMC and benefit from:

- fast, convenient online submission

- thorough peer review by experienced researchers in your field

- rapid publication on acceptance

- support for research data, including large and complex data types

- gold Open Access which fosters wider collaboration and increased citations

- maximum visibility for your research: over $100 \mathrm{M}$ website views per year

At BMC, research is always in progress.

Learn more biomedcentral.com/submission 